University of Rhode Island

DigitalCommons@URI

Open Access Master's Theses

1977

\title{
Investigations of the Striped Bass, Morone saxatilis (Walbaum), Overwintering in the Upper Petaquamscutt River Estuary
}

John F. O'Brien

University of Rhode Island

Follow this and additional works at: https://digitalcommons.uri.edu/theses

\section{Recommended Citation}

O'Brien, John F., "Investigations of the Striped Bass, Morone saxatilis (Walbaum), Overwintering in the Upper Petaquamscutt River Estuary" (1977). Open Access Master's Theses. Paper 767.

https://digitalcommons.uri.edu/theses/767

This Thesis is brought to you for free and open access by DigitalCommons@URI. It has been accepted for inclusion in Open Access Master's Theses by an authorized administrator of DigitalCommons@URI. For more information, please contact digitalcommons-group@uri.edu. 
INVESTICATIONS OF THE STRIPED BASS, Morone saxatilis

(Walbaum), OVERWINTERING IN THE UPPER

PEITAQUAMSCUTT RIVERR ESTUARY

by

JOHN F. O'BRIEN

A THESIS SUBMITTED IN PARTIAL FULFILIMENT OF THE REQUTREMIENTS FOR THE DEGRFE OF

MASTER OF SCIENCE

IN

ANIMAL SCIENCE

UNIVERSITY OF RHODE ISLAND

1977 


\section{MASTER OF SCIENCE THESIS}

\section{OF}

JOHN F. O'BRIEN

Approved:

Thesis Committee:

Major Professor

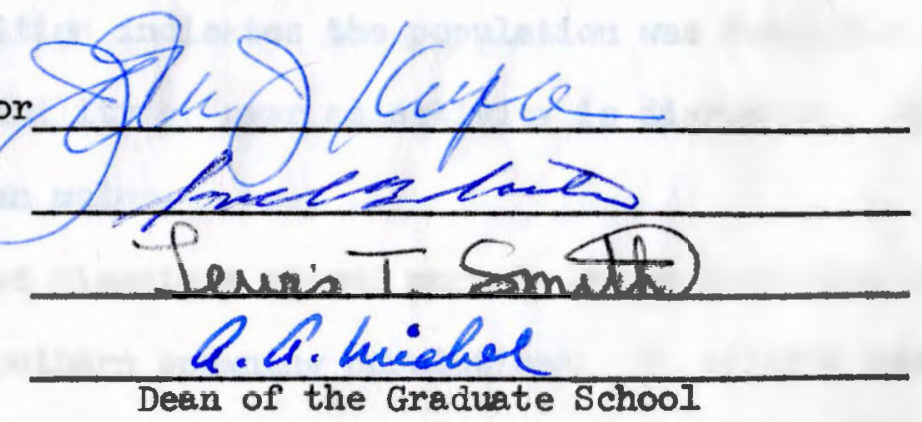

UNIVERSITY OF RHODE ISIAND 
ABSTRACT

The upper Pettaquanscutt River Estuary contains a unique overwintering population of striped bass, Morone saxatilis (Walbaum). During the winters of 1974 and 1975, experimental gillnets were used to sample this population. Catch data was examined in relation to abundance and distribution. Length, weight, and sex of individuals were recorded and ovaries were examined. Ichthyoplankton samples taken in the area during May and Jume of 1974 were examined for evidence of successful striped bass spawning.

A limited number of striped bass were gillnetted from the sample area. Nine were netted during 1974 and eleven during 1975. Ice limited sampling during the early winter. Gillnets were removed on April 15, and May 15 during 1974 and 1975 respectively. During both winters of sampling, bass were not taken from the sample area after the beginning of April, suggesting that they had left the area.

Age class composition indicates the population was dominated by older fish. The possibility of gear selectivity is discussed. Females were more abundant than males.

Measuremont of ova diameters showed normal development when compared with those of southern spawning populations. No striped bass eggs or larvae were identified from ichthyoplankton samples. High salinities may limit the potential of this area as a natural spawning ground. 


\section{ACKNOWLEDG EMENTS}

I gratefully acknowledge the assistance of all those who contributed to the completion of this work. I would like to express my thanks to the members of my committee for their guidance and assistance. Special thanks to Dr. John Kupa for his generous support throughout my graduate career at URI. Also, special thanks to Bruce Rogers and Deborah Westin of the URI Marine Experiment Station for the use of their reference material and sampling equipment. I am grateful for the advice and cooperation which I received from Dr. Lewis T. Smith. I would like to express my appreciation to John Stolgitis of the Rhode Island Division of Fish and Wildlife for arranging financial support for this study. "Slim" Borsay was very generous to allow me to use his docking facilities while working in the study area. I would also like to thank Jo-Anne Farrell for her work as typist. Lest, but not least, I wish to thank my wife Karen for her constant support and encouragement.

This research was supported by Federal Aid to Fisheries through the Rhode Island Division of Fish and Wildlife, project reference F-26-R-9, IV. 
TABLE OF CONTENTS

Page

I. INTRODUCTION................................ 1

II. REVIEW OF LITERATURE........................... 3

III. MATERIAIS AND METHODS........................... 8

IV. RESULTS.................................... 14

Abundance and Distribution..................... 14

Population Structure........................... 19

Spawning................................... 21

v. DISCUSSION................................ 27

Abundance and Distribution...................... 27

Population Structure........................... 29

Spawning................................. 32

VI. CONCLUSTONS..................................... 34

VII. IITERATURE GITED............................ 35

VIII. APPENDIX.................................... 38 


\section{IIST OF FIGURES}

Figure

Page

1. The Pettaquamscutt River Estuary, located along the west side of Rhode Island's Narragansett Bay

2. Iocations used for setting experimental gillnets in the upper Pettaquamscutt River Estuary. Stations G-1a through G-10a were sampled during 1974. Stations G-1b, $\mathrm{G}-2 \mathrm{~b}$, and $\mathrm{G}-3 \mathrm{~b}$ were sampled during $1975 \ldots \ldots \ldots \ldots \ldots$

3. Locations of fyke net and ichthyoplankton stations, in the upper Pettaquamscutt River Estuary, sampled during

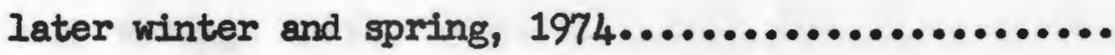

4. Sample means of ova diameters of overwintering striped bass taken from the upper Pettaquamscutt River Estuary 


\section{LIST OF TABLES}

Table

Page

1. Frequency of occurrence for overwintering striped bass gillnetted in the Pettaquamscutt River Estuary, Jan-

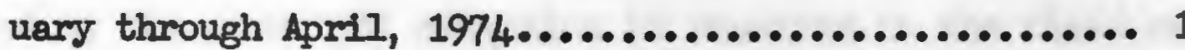

2. Twenty-four hour catch taken in a fyke net set on eight occasions, in the Pettaquamscutt River Estuary, 1974

3. Frequency of occurrence for overwintering striped bass gillnetted in the Pettaquamscutt River Estuary, January through April, $1975 \ldots \ldots \ldots \ldots \ldots \ldots \ldots \ldots \ldots \ldots \ldots \ldots \ldots 18$

4. Date of cepture, sex, length, (cm.), weight (kg.), and age of overwintering striped bass taken from the Pettaquamscutt River Estuary, 1974 and 1975............. 20

5. Year class frequency of overwintering striped bass taken fron the Pettaquanscutt River Estuary, 1974 and 1975

6. Stomach contents of twenty overwintering striped bass taken from the Pettaquamscutt River Estuary, 1974 and 1975 


\section{INTRODUCTION}

The striped bass, Morone saxatilis (Walbaum), is one of the most valued saltwater gamefish along the coast of Rhode Island. Its importance as both a sport and commercial species along the entire Atlantic coast is reflected by the amount of attention it receives in the field of fishery science.

Striped bass occur in Rhode Island only as a migrant species (Bigelow and Schroeder, 1953). Their coastal migration patterns are well known. Each spring a certain percent of bass fron the Chesapeake Bay travel northward into the northeast coastal waters, on a non-spawning migretion. This pattern is reversed in the fall and the fish return to Chesapeake waters. Perhaps the most notable exception to this pattern is the tendency of a small number of fish to remain behind and overwinter in various New Fngland rivers and estuaries (Merriman, 1941). For many years, knowledge of an overwintering population of striped bass in the Pettaquanscutt River Estuary of Rhode Island has been shared by a relatively few commercial and sport fishermen.

Although there are no reports of young of the year striped bass being found in the area, the presence of these overwintering fish has always stimulated discussion of the possibility of striped bass spawning occurring in the Pettaquanscutt system.

The status of the overwintering population and its role in using this estuary as a spawining ground has never been documented. The objective of this study was to investigate the overwintering populations of striped bass in the upper Pettaquamscutt River Estuary in an attempt 
to provide insight into its abundance, population structure, and spaming status. 


\section{ITTERATURE REVIEW}

The striped bass is an anadromous fish native to the Atlantic coast of North America. This species occurs from the St. Lawrence River in Canada to the St. Johns River in Florida and is also found in the Gulf of Mexico (Bigelow and Schroeder, 1953). Striped bass have also been introduced to the West coast and into a number of large fresh water impoundments. A comprehensive bibliography on the biology of the striped bass has been compiled by Rogers and Westin (1975). Important contributions to Iife history reviews include Merriman (1941), Raney (1952), Talbot (1966), and Vladykov and Wallace (1952).

A summary of work conducted on striped bass migration (Porter and Saila, 1969) shows that a small portion of Chesapeake Bay striped bass make up the major portion of migrating bass found along the middle Atlantic and New England coast. Chapoton and Sykes (1961) separated these migratIng populations into two categorles: bass ranging between 1 and 6 pounds and bass between 6 and 75 pounds. The latter group make up a small portion of the migrants.

Tagging studies conducted by Nichols and Miller (1967), Hollis and Davis (1955), and Mansueti (1961) support a certain predictability in the migration patterns of these fish. Cemerally, striped bass do not begin to migrate north until their third year of life. For the adults, the seasonal migrations begin in the spring, shortly after spawning, while juveniles may migrate earlier. The fish will reside in various New England bays and estuaries throughout the summer and return south in the late fall. Mansueti (1961), Nichols and Miller (1967), and 
Moore and Burton (1975) suggest the existence of a homing tendency in striped bass to return to the same river to spawn.

Certain exceptions to the above model have been discussed. Merriman (1941), referred to the Parker River in Massachusetts as "an example of an isolated spaming area in northern waters supported at least in part by a resident population and possibly added to by migrants from the soith in exceptional years". Although little spawning has ever been reported in this location, the presence of overwintering fish is well documented. In addition to the resident isolated populations, and the fish which have their origin in southern waters but spend an occasional winter in northern waters, Bigelow and Schroeder (1953) suggest the possibility of a third case: those which come from the south and remain in the north for the rest of their lives.

Another area known for its yearround population of striped bass is the Thames River Estuary, Connecticut. The results of tagging studies conducted in this system (Moltezos, 1961) indicated that the existing population within the estuary was not indigenous but merely overwintered from one to two years at a time. Maltezos also considered the question of spawning in the Thames River Estuary. Based on the development of the granular mass in the ovaries, only a small percentage of mature female ovaries were in the developing stage. Intensive seining for young-of-the-year striped bass in the area produced negative results. It was concluded that spawning may occur in the Thames but contributes little if anything to the fishery.

Except for the accounts of sport and commercial fishermen, there is little information on the overwintering population of striped bass in 
the Pettaquanscutt River Estuary.

The Pettaquamscutt River Estuary is located in southern Rhode Island along the west side of Narragansett Bay (Figure 1). It has a north-south orientation running along $71^{\circ}, 27^{\prime}$ longitude and botween $41^{\circ}, 31^{\prime}$ and $41^{\circ}, 25 ; 30^{\prime \prime}$ latitudes. Described by Horton (1958) as a fjord like river, this drowned valley type estuary is approximately 9 kilometers in length from its fresh water source, Gilbert Stuart Brook, to the lower West Passage of Narragansett Bay. Studies of the spring zooplankton populations of the upper portion of the Pettaquamscutt River Estuary (Smayda and Jefferies, 1954) show Eurytemora hirundoides to be the dominant species. A survey of shellfish, and the distribution of salinity and bottom type are found in Wright et aㅡ. (1958).

Seasonal distributions of fish were first determined by Horton (1958). Striped bass were not taken during the winter sampling. The only other account of fish populations is found in Mulkana (1966). The juvenile populations of the lower and middle portion of the estuary were examined. Growth rates of these juveniles were favorable when compared to other systems. No juvenile striped bass were found during the sampling.

A description of the phytoplaniton of the upper portion of the estuary is found in Miller (1972). Excellent accounts of the hydro graphy, geology and chemistry of the estuary are found in Smayda and Jefferies (1954), Horton (1958), and Miller (1972). Most recently a comprehensive investigation was conducted by Gaines (1975), covering the geomorphology, hydrology and geochemistry. 
The entire system can be divided into four sections (Gaines, 1975): (1) Pettaquamscutt Cove and the narrows at the southern most end; (2) the central river from Middle Bridge to Bridgetom Bridge; (3) the upper river including the two Pettaquemscutt ponds; and (4) the fresh water source or Gilbert Stuart Brook. The present study is primarily concerned with the upper river. Both ponds were formed by ice block depressions and contain highly stratified brackish water.

Bathymetry of the upper river is found in Horton (1958). The lower pond has a maximum depth of 60 feet (18 meters) and the upper pand extends to 40 feet ( 12 meters) in maximum depth. Fresh water entering the system flows over brackish tidal water entering from Narragansett Bay. This stratification eventually leads to anoxic basins in both ponds. They are separated from each other and the rest of the estuary by shallow sills. The lower basin remains permanently stratified; however, annual overturn occurs irregularly in the upper basin (Horton, 1958 and Gaines, 1975). 
Figure 1. The Pettaquamscutt River Estuary, located along the west side of Rhode Island's Narragansett Bay. 


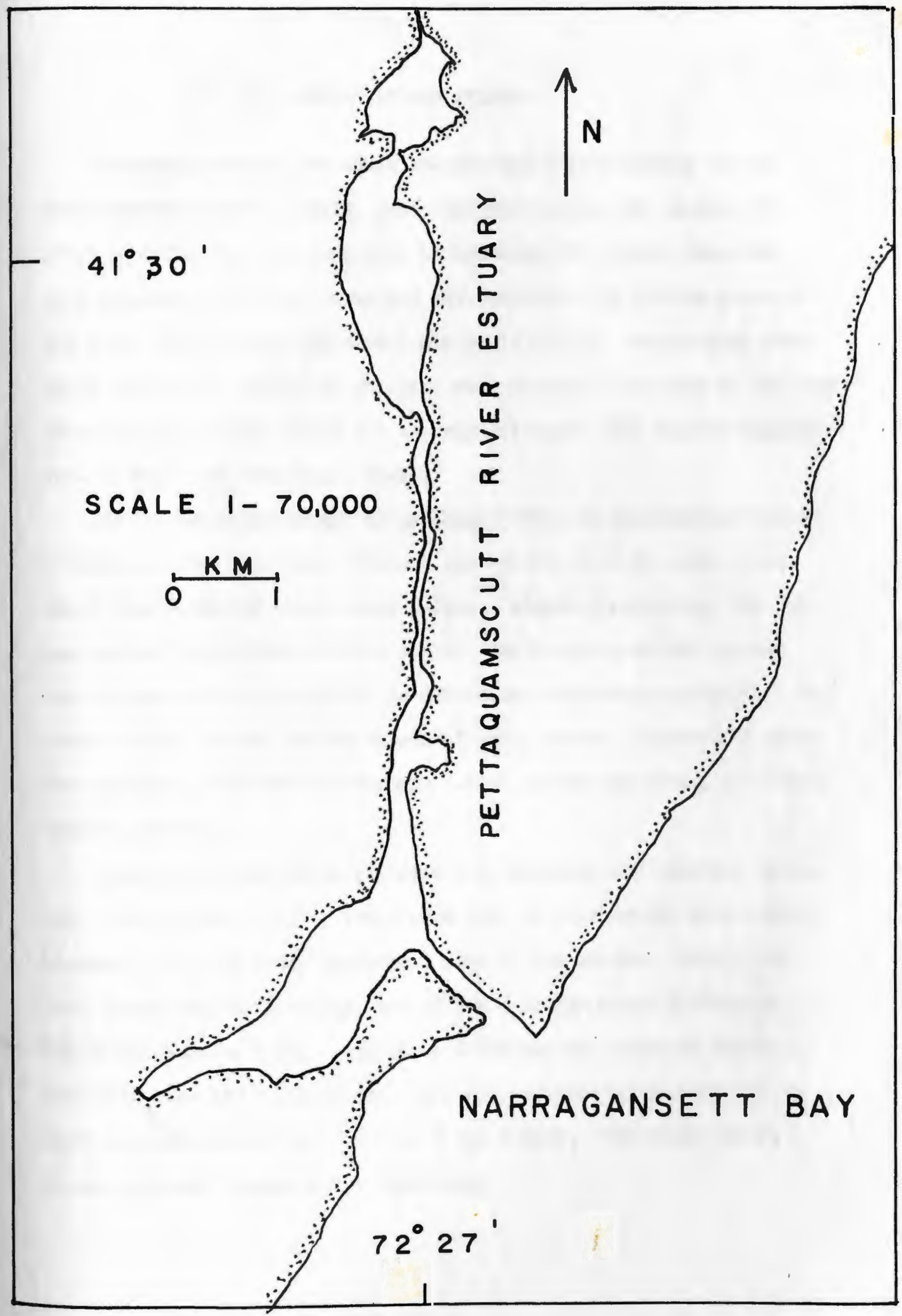




\section{MATERIALS AND METHODS}

Sampling programs for adult striped bass overwintering in the Pettaquamscutt River Estuary, were conducted during the winters of 1974 and 1975. Efforts were made to determine if striped bass were in a spawning condition. Sampling was restricted to the two ponds of the upper river during the winter and early spring. Any striped bass taken during this period of the year were assumed to be part of the overwintering population, since all the migrants have left the New Ingland area by this time (Merriman, 1941).

During the first winter of sampling (1974) an experimental monofilament gillnet was used. The net was $150 \mathrm{ft}$. by $6 \mathrm{ft}$. with 4 in. square mesh, and was set to tend bottom. Weather permitting, the net was checked daily from a $16 \mathrm{ft}$. skiff. The location of the net was changed at random in an effort to determine distribution patterns. The depth of each station varied between 2 and 5 meters. Figure (2) shows the location (stations $\mathrm{G}-1 \mathrm{a}$ through $\mathrm{G}-10 \mathrm{a}$ ) of the net during the first sampling season.

Two experimental nylon gillnets were obtained for sampling during the second winter (1975). These were kept at permanently established stations ( $G-1 b$ and $G-2 b$ ) throughout most of the winter. During the late winter and early spring, one of the nets was moved further up the river (station G-3b). All three locations are shown in figure 2. Both nets were $150 \mathrm{ft}$. by $8 \mathrm{ft}$. Each net was made up of three $50 \mathrm{ft}$. sections with mesh sizes 3,4 , and $5 \mathrm{in}$. square. Both nets tended bottom and were checked every other day. 
Figure 2. Locations used for setting experimental gillnets in the upper Pettaquanscutt River Estuary. Stations G-1a through G-10a were sampled during 1974. Stations G-1b, $\mathrm{G}-2 \mathrm{~b}$, and $\mathrm{G}-3 \mathrm{~b}$ were sampled during 1975. 


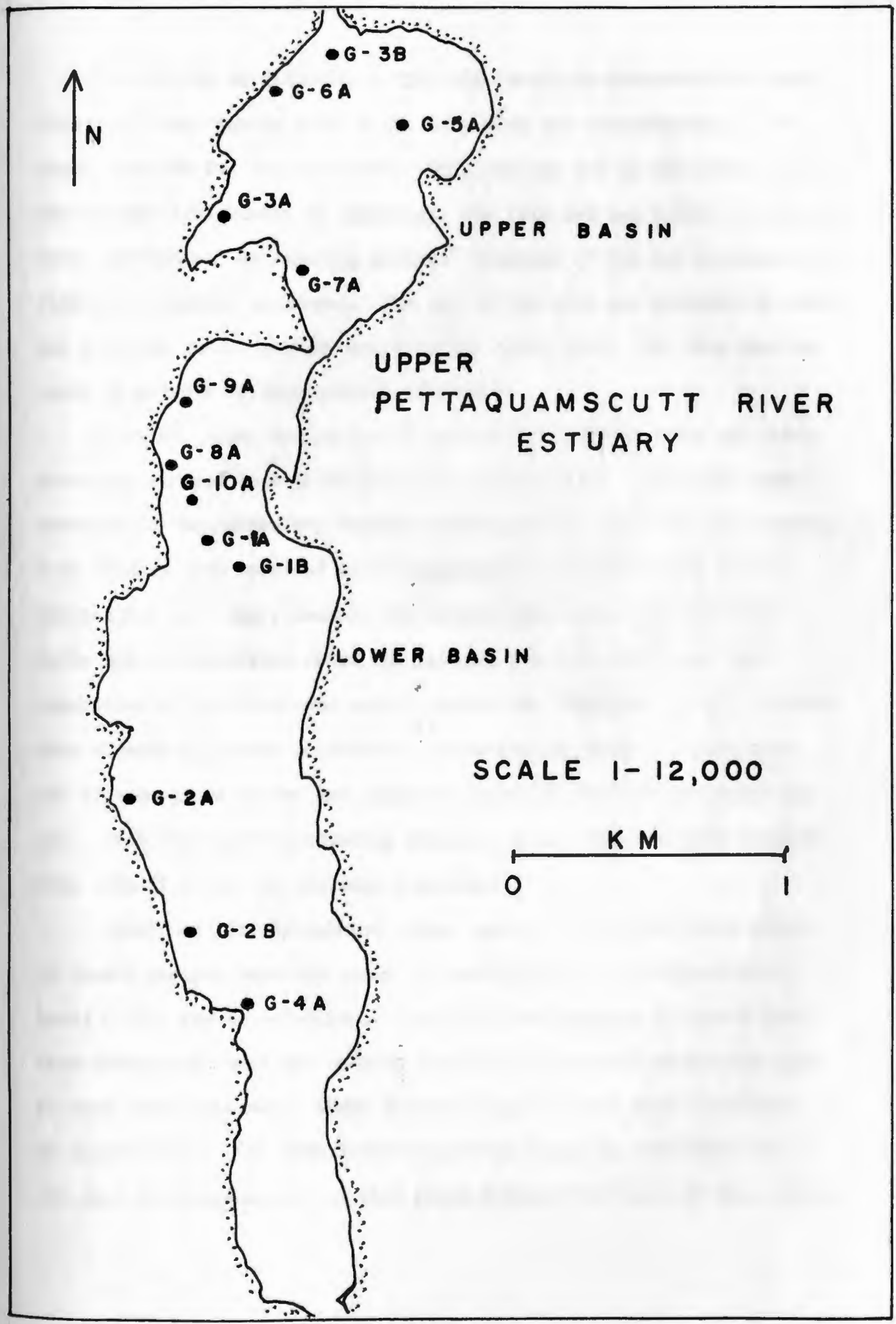


In addition to gillnets, a fyke net (modified Massachusetts type) with a $0.75 \mathrm{in}$. square mesh, $4 \mathrm{ft}$. trap with two compartments, $25 \mathrm{ft}$. wings, and $100 \mathrm{ft}$. lead was used. This net was set in the study area during the first winter of sampling. The fyke net was fished on various dates throughout the sampling period. Iocation of the net (station F-1, figure 3) remained unchanged. The end of the lead was attached to shore and extended out at a right angle to the shore line. The trap was located at a depth of approximately 2 meters.

Location, date, and method of capture were recorded for all overwintering striped bass taken from the sampling area. Specimens were examined in the laboratory shortly after capture. All fish were sexed. Fork lengths were recorded to the nearest $0.5 \mathrm{~cm}$. and weight to the nearest $0.1 \mathrm{~kg}$. Approximately six scales were taken from the first white horizontal stripe above the lateral line directly under the separation of the first and second dorsal fin (Merriman, 1941). Scales were cleaned in a mild solution of potassium hydroxide. Scales were put between glass slides and placed in a Bausch and Lomb projector at 42X. Fish were aged by counting annular rings. Stomachs were removed from each fish and the contents examined.

Techniques for determining sexual maturity and ovary development of female striped bass are found in Lewis (1961). The objective of Iewis (1961) was to establish criteria for determining if female bass from Albermarle Sound had reached maturity. Ovaries from various ages of bass were inspected. Three distinct sizes of ova were identified by Iowis (1961): (1) translucent ova which range in size from .OS to $.23 \mathrm{~mm} . ;$ (2) translucent ova that range between 0.16 and $.30 \mathrm{~mm}$, and in 
Flgure 3. Locations of fyke net and ichthroplankton stations, in the upper Pettaquamscutt River Estuary, sampled during late winter and spring 1974 . 


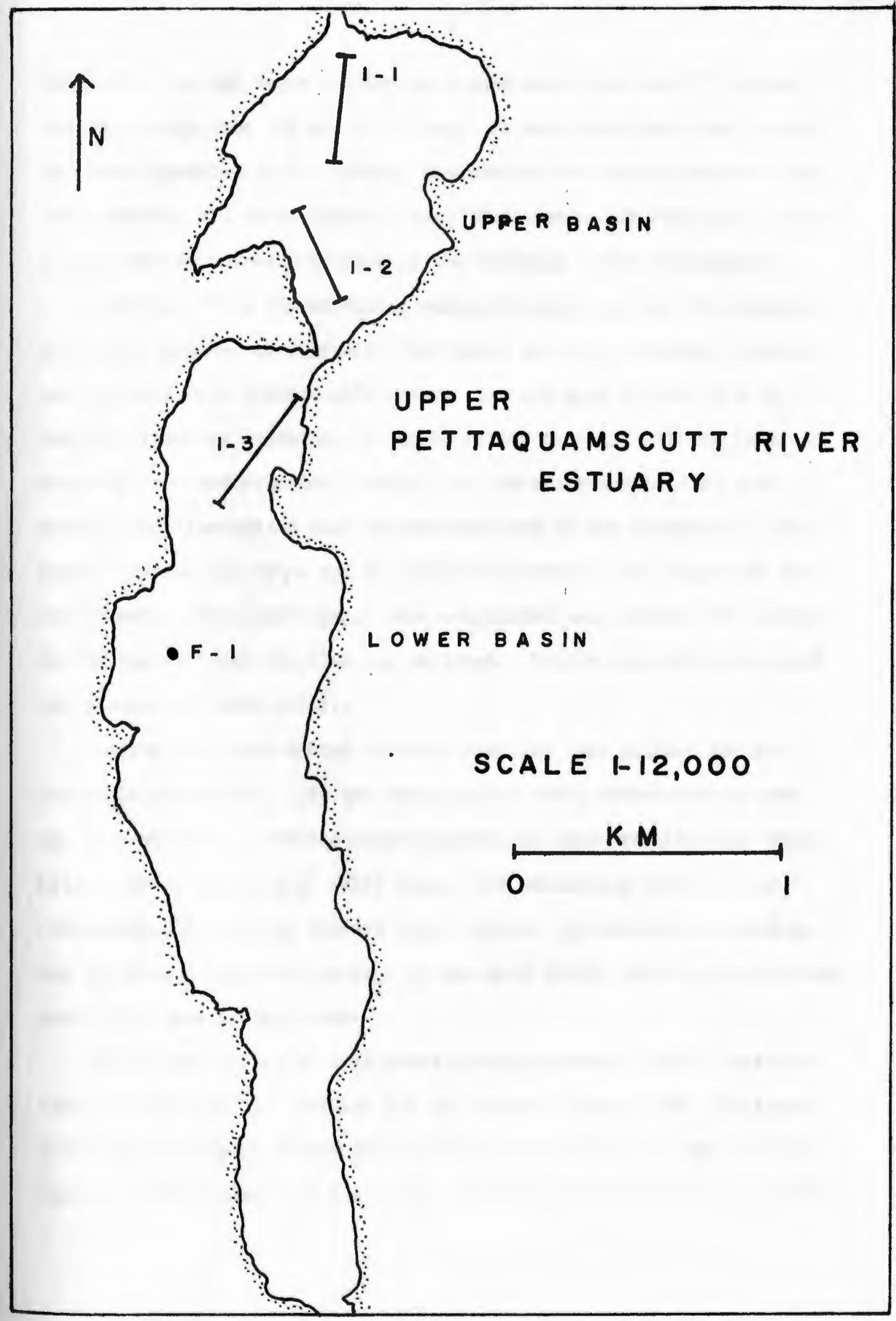


which the yolk had begrn to form as opaque speckling; and (3) opaque ova that range from $.33 \mathrm{mn}$. to $1.0 \mathrm{~mm}$. It was shown that from September until spawning in the spring, the ovaries of sexarally mature fish would contain all three types of ova. Measurements of the type (3) ova also showed an increase in size as the spawning season approached.

Ovaries of all overwintering striped bass taken from the sampling area were examined to determine the fish's stage of maturity. Ovaries were removed from all sexually mature fish and were placed in a $5 \%$ buffered formalin solution. A sample of 100 type (3) ova was taken randomly from the anterior, middle, and posterior sections of each ovary. The diameter of each ova was measured to the nearest $0.05 \mathrm{~mm}$. using a dissecting scope and an ocular micrometer. The range and mean ova diameters from each sample were calculated and plotted with respect to the time of year the fish was captured. Coaparisons were made with the results of Iewis (1961).

During the first winter of adult sampling, the gilinet was not available after April 15th and sampling for adult overwintaring bass was discontinued. Previous investigations in this area (Horton, 1954; Miller, 1972; and Gaines, 1975) report low salinities close to the freshwater influence of Gilbert Stuart Brook. If successful spawning had occurred during that spring, it was most likely that eggs and larvae would have been in that area.

During the spring of 1974 three ichthyoplankton stations were established (Figure 3). Station I-1 was located close to the freshwater Influence of Gilbert Stuart Brook in the upper pond. I-2 and I-3 were located further down from the brook. Stations were sampled every third 
day. From a $16 \mathrm{ft}$. skiff a 0.5 meter plankton net (E.M. MPg. Co., No. 0 mesh) was towed on both surface and bottom for approximately five minutes. All samples were immediately preserved in a 5 to $10 \%$ buffered formalin solution. Temperature and salinity readings were taken at each station using an electrodless induction salinometer (Industrial Instruments, RS5-3 Portable Salinometer). Readings were taken at both top surface and bottom of station locations.

Samples were examined in the laboratory using a dissecting microscope. Fish, eggs, and larvae were sorted and placed in a $3 \%$ buffered formalin solution. Collections were checked for striped bass eggs and larvae using the description of Mansueti (1958). Other species of eggs and larvae were not identified. 


\section{RESULTS}

\section{Abundance and Distribution}

During the first winter (1974) of sampling a total of nine adult bass were taken in the gillnet. The presence of Ice on both ponds prevented sampling until January 30th. Ice appeared again on February 4th and it was not possible to reset the net until February 27 th. The net was then fished continuously until April 15th.

Throughout the sampling period the gillnet was checked daily with few exceptions. Every few days the gillnet was relocated to another station within the upper two ponds. Table (1) shows the dates during which each station was sampled and the corresponding catch. A total of seven striped bass were taken from station $\mathrm{G}-1 \mathrm{a}$ and two from station G-10e. Both stations were located in the same general area within the lower pond (Figure 2). Striped bass appeared in the gillnet as soon as sampling began on the 30th of January. The last fish was taken on April 3rd. Flsh did not appear in the gillnet in any regular pattern. Since the net was moved about randomly, it was difficult to determine any trends in frequency of capture. Two adult striped bass taken by sport fishermen were also examined. These fish were also taken in the southern basin. The first fish was observed on the 28th of December and the second on the 30th of March.

No striped bass were taken in the fyke net. This net was used a total of elght times throughout the first sampling season. It was set for twenty-four hour periods in the lower pond. The location of the net was not changed during the sampling season. Only winter flounder 
Table 1

Frequency of occurrence for overwintering striped bass gillnetted in the Pettaquamscutt River Estuary, January through April, 1974.

\begin{tabular}{|c|c|c|c|c|c|c|c|c|}
\hline Dat & te & Sta. No. & No. & Fish & & Sta. No. & & D. Fish \\
\hline \multirow[t]{3}{*}{ Jan. } & $1-29$ & Ice-not able & to $s$ & sample & 17 & $G-7 a$ & & 0 \\
\hline & 30 & $G-1 a$ & & 0 & 18 & $G-7 a$ & & 0 \\
\hline & 31 & $G-1 a$ & & 1 & 19 & $G-8 a$ & & 0 \\
\hline \multirow{2}{*}{ Feb. } & 1 & $G-1 a$ & & 1 & 20 & $G-8 a$ & & 0 \\
\hline & 2 & $G-1 a$ & & 0 & 21 & $G-8 a$ & & 0 \\
\hline & 3 & $G-1 a$ & & 0 & 22 & $G-9 a$ & & 0 \\
\hline & $4-26$ & Ico-not able & to $s$ & sample & 23 & $G-9 a$ & & 0 \\
\hline \multirow{2}{*}{ tw } & 27 & $G-1 a$ & & 1 & 24 & $G-9 a$ & & 0 \\
\hline & 28 & $G-1 a$ & & 0 & 26 & $G-9 a$ & & 0 \\
\hline \multirow{2}{*}{ Mar. } & 1 & $G-1 a$ & & 1 & 27 & $G-10 a$ & & 1 \\
\hline & 2 & $G-1 a$ & & 2 & 28 & $G-10 a$ & & 0 \\
\hline \multirow{4}{*}{. } & 3 & G-1a & & 0 & 30 & $G-10 a$ & & 0 \\
\hline & 4 & $G-1 a$ & & Apr. & 2 & $G-10 a$ & & 1 \\
\hline & 7 & $G-3 a$ & & 0 & 3 & $G-5 a$ & & 0 \\
\hline & 8 & $G-3 a$ & & 0 & 6 & $G-5 a$ & & 0 \\
\hline \multirow{2}{*}{$=$} & 10 & $G-3 a$ & & 0 & 7 & $G-5 a$ & & 0 \\
\hline & 11 & $G-4 a$ & & 0 & 9 & $G-7 a$ & & 0 \\
\hline \multirow[t]{5}{*}{1} & 12 & $G-4 a$ & & 0 & 10 & $G-7 a$ & & 0 \\
\hline & 13 & $G-5 a$ & & 0 & 13 & $G-1 a$ & & 0 \\
\hline & 14 & $G-5 a$ & & 0 & 14 & $G-1 a$ & & 0 \\
\hline & 15 & $G-6 a$ & & 0 & 15 & $G-1 a$ & & 0 \\
\hline & 16 & $G-6 a$ & & 0 & & & & \\
\hline
\end{tabular}


(Pseudopleuronectes americanus), white perch (Morone americana), and alewives (losa pseudoharengus) were taken in the net. Results of the fyke net sampling are summarized in Table (2). The fyke net was not used during the following season.

A total of eleven overwintering striped bass were taken in gillnets during the second winter (1975) of sampling (Table 3). Ice, which formed over both the upper ponds at the end of December remained until the end of February. Gillnetting began on February 26th and continued until the 15th of May. Two gillnets were used and each net was kept at permanent locations for the duration of the winters sampling. The location of Net 1 (station $G-1 b$ ) was chosen on the basis of the previous years success. The location of gillnet 2 (station $G-2 b$ ) was chosen as a result of information gained from commercial fisherman familiar with the area (Wilfred Clark, personal communication).

Both nets were checked every other day. Striped bass first appear ed in the nets shortly after they were set (March 6th). Until the 8th of April, bass were taken from the sample area on the average of one every three days. This figure included the catch of both nets. Five bass were taken from station $G-1 b$ and six from station $G-2 b$.

On April 20th net 2 was relocated to the upper pand (station G-3b). It was possible that the overwintering bass in this system might have moved further up toward the freshwater influence of Gilbert Stuart Brook as water temperature increased. Spawning would have occurred in this area since low salinity is one of the prerequisites for striped bass spawning (Talbot, 1966). During this twenty-five day period, no fish were taken either at this location $(G-3 b)$ or at station $G-1 b$. The 


\section{Table 2}

Twenty-four hour catch taken in a fyke net set on eight occasions, in the Pettaquamscutt River Bstuary, 1974.

\begin{tabular}{cccc}
\hline Date & Flounder & White Perch & Alewife \\
\hline Jan. 31 & 125 & 30 & \\
Feb. 1 & 95 & 18 & \\
27 & 30 & 55 & \\
Mar. 1 & 30 & 25 & \\
4 & 24 & 4 & 8 \\
12 & 75 & 5 & 4 \\
28 & 15 & 75 & 2 \\
Apr. 3 & 6 & 10 & \\
\hline
\end{tabular}


Table 3

Frequency of occurrence for overwintering striped bass gillnetted in the Pettaquanscutt River Estuary, January through May, 1975.

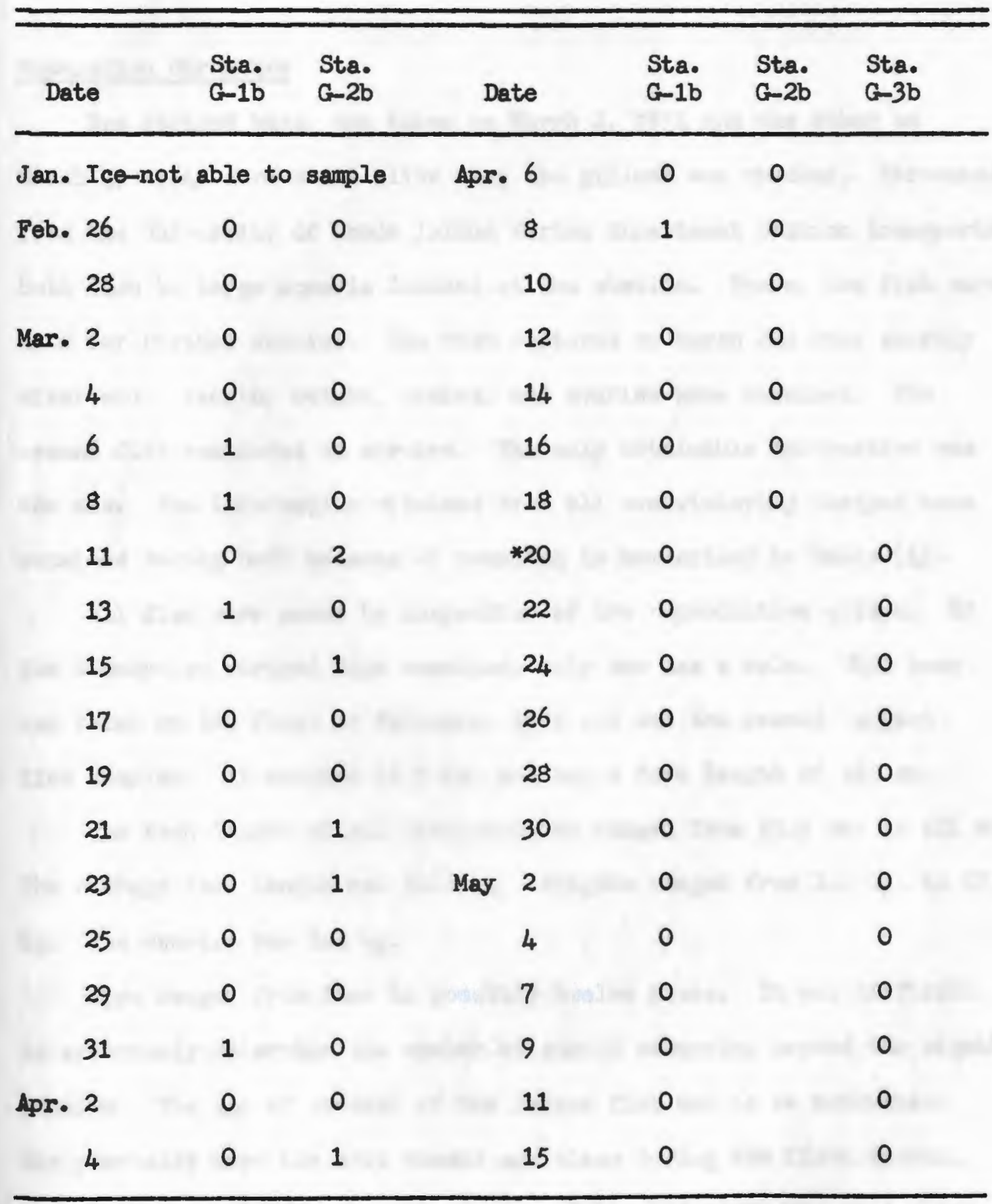

*Net 2 relocated to station G-3b 
last striped bass to be taken during the second winter of sampling was taken on April 8th. Both nets were removed from the study area on May 15th.

\section{Population Structure}

Two striped bass, one taken on March 2, 1974 and the other on March 4, 1974, were still alive when the gillnet was checked. Personnel from the University of Rhode Island Marine Experiment Station transported both fish to large aquaria located at the station. There, the fish were used for further studies. The fish captured on March and died shortly afterward. Ingth, weight, scales, and ovaries were obtained. The second fish continued to survive. The only obtainable information was the sex. The information obtained from all overwintering striped bass examined during both seasons of sampling is summarized in Table (4).

All fish were sexed by inspection of the reproductive system. Of the twenty-two striped bass examined, only one was a male. This bass was taken on the first of February, 1974 and was the second largest fish sampled. It weighed $16.5 \mathrm{~kg}$. and had a fork length of $121 \mathrm{~cm}$. The fork length of all fish measured ranged from $55.5 \mathrm{~cm}$. to $121 \mathrm{~cm}$. The average fork length was $86.2 \mathrm{~cm}$. Weights ranged from $2.0 \mathrm{~kg}$. to 17.5 kg. The average was $8.2 \mathrm{~kg}$.

Ages ranged from four to possibly twelve years. It was difficult to accurately determine the number of annuli occurring beyond the eighth annulus. The age of several of the larger fish had to be estimated. Six year-olds were the most common age class during the first season, and eight year-olds during the second. Table (5) shows the year class 
Table 4

Date of capture, sex, length $(\mathrm{cm} \cdot)$, welght $(\mathrm{kg})$, and age of overwintering striped bass taken from the Pettaquanscutt River Estuary, 1974 and 1975.

Date of

Capture

Sex

Iength

Weight

Age

$12 / 28 / 73 *$

F

90.0

10.4

8

$1 / 31 / 74$

81.5

$7 \cdot 5$

6

$2 / 1 / 74$

121.0

16.5

$10-12$

$2 / 27 / 74$

85.0

$7 \cdot 3$

6

$3 / 1 / 74$

84.0

9.1

7

$3 / 2 / 74$

87.0

9.1

6

$3 / 2 / 74$

69.0

3.6

5

$3 / 4 / 74$

F

Not Available

$3 / 20 / 74 *$

111.0

$17 \cdot 5$

10-12

$3 / 27 / 74$

93.0

11.3

9

$4 / 2 / 74$

78.0

5.6

6

$3 / 6 / 75$

78.5

4.8

6

$3 / 8 / 75$

82.2

5.8

7

$3 / 11 / 75$

62.0

2.1

5

$3 / 11 / 75$

87.5

$7 \cdot 0$

8

$3 / 13 / 75$

88.5

8.2

7

$3 / 15 / 75$

62.0

2.0

5

$3 / 21 / 75$

89.5

8.6

8

$3 / 23 / 75$

103.5

13.9

9-10

$3 / 31 / 75$

F

90.0

9.1

8

4/4/75

F

95.0

11.5

8

$4 / 8 / 75$

F

55.5

2.2

4 
frequently combined for both seasons of sampling. The few fish which could not be aged accurately are represented by the lowest year class within its suspected range.

Examination of the stomach contents of twenty overwintering bass showed eight (40\%) to be empty (Table 6). Prey, when present, consisted of winter flounder (Pseudopleuromectes americanus), alewives (Alosa pseudohorengus), and shrimp (Palaemonetes sp.). Only winter flounder were observed in stomachs during the months of January and February. Flounder were also the most common prey, appearing in seven of the thir teen stamachs containing food items. Alewives did not appear as part of the stomach contents until the month of March, when they also appeared in the gillnets. Flounder continued to be utilized as food even after alewlves appeared in the sampling area. Invertebrates were only observed in the stomach of one fish $(3 / 11 / 75)$.

\section{Spaming}

Samples of ova were obtained from the ovaries of sixteen mature females. Four females were immature and one female was being kept alive at the Marine Experiment Station. Figure (4) shows the range and average of ova diameter for 100 type (3) ova (Iewis, 1961), taken from each female, with respect to the time of year captured. Figure (4) also compares the size of type (3) ova of overwintering bass in the Pettaquamscutt, with the minimum size of type (3) ova from striped bass in Albermarle Sound ( Iewis, 1961).

Measurements of the ova diameter serve only to determine the condition of the ovaries and indicate the spawing potential of the fish. 
Table 5

Year class frequency of overwintering striped bass taken from the Pettaquamscutt River Estuary, 1974 and 1975.

\begin{tabular}{|c|c|c|c|c|c|c|c|c|c|c|}
\hline Year Class & 1962 & 1963 & 1964 & 1965 & 1966 & 1967 & 1968 & 1969 & 1970 & 1971 \\
\hline No. caught in 1974 & 1 & & 1 & 1 & 1 & 1 & 4 & 1 & & \\
\hline No. caught in 1975 & & & & & 1 & 4 & 2 & 1 & 2 & 1 \\
\hline Total & 1 & & 1 & 1 & 2 & 5 & 6 & 2 & 2 & 1 \\
\hline Percent of total & $4 \cdot 5$ & & $4 \cdot 5$ & $4 \cdot 5$ & 9.0 & 22.7 & $27 \cdot 7$ & 9.0 & 9.0 & $4 \cdot 5$ \\
\hline
\end{tabular}

N 
Table 6

Stomach contents of twenty overwintering striped bass taken from the Pettaquamscutt River Estuary, 1974 and 1975.

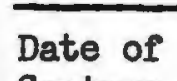

Capture

Flounder

Alewife

Invertebrate

Empty

$12 / 28 / 73 \quad X$

$1 / 31 / 74 \quad \mathrm{X}$

$2 / 1 / 74 \quad \mathrm{X}$

$2 / 27 / 74$

$\mathrm{X}$

$3 / 1 / 74 \quad x$

$3 / 2 / 74$

$\mathrm{x}$

$3 / 20 / 74$

$\mathbf{x}$

$3 / 27 / 74$

$\mathrm{X}$

$4 / 2 / 74$

$\mathbf{x}$

$3 / 6 / 75$

$\mathbf{x}$

$3 / 8 / 75$

$\mathrm{x}$

$3 / 11 / 75$

$\mathrm{X}$

$3 / 11 / 75$

$\mathrm{x}$

$3 / 13 / 75$

$\mathbf{X}$

$3 / 15 / 75$

$\mathbf{x}$

$3 / 21 / 75$

$\mathbf{x}$

$3 / 23 / 75$

$\mathrm{X}$

$3 / 31 / 75$

$\mathrm{x}$

4/4/75

$\mathrm{X}$

$4 / 8 / 75$

$\mathrm{X}$ 
Figure 4. Sample means type (3) of ova diameters of overwintering striped bass taken from the upper Pettaquamscutt River Estuary during 1974 and 1975. 


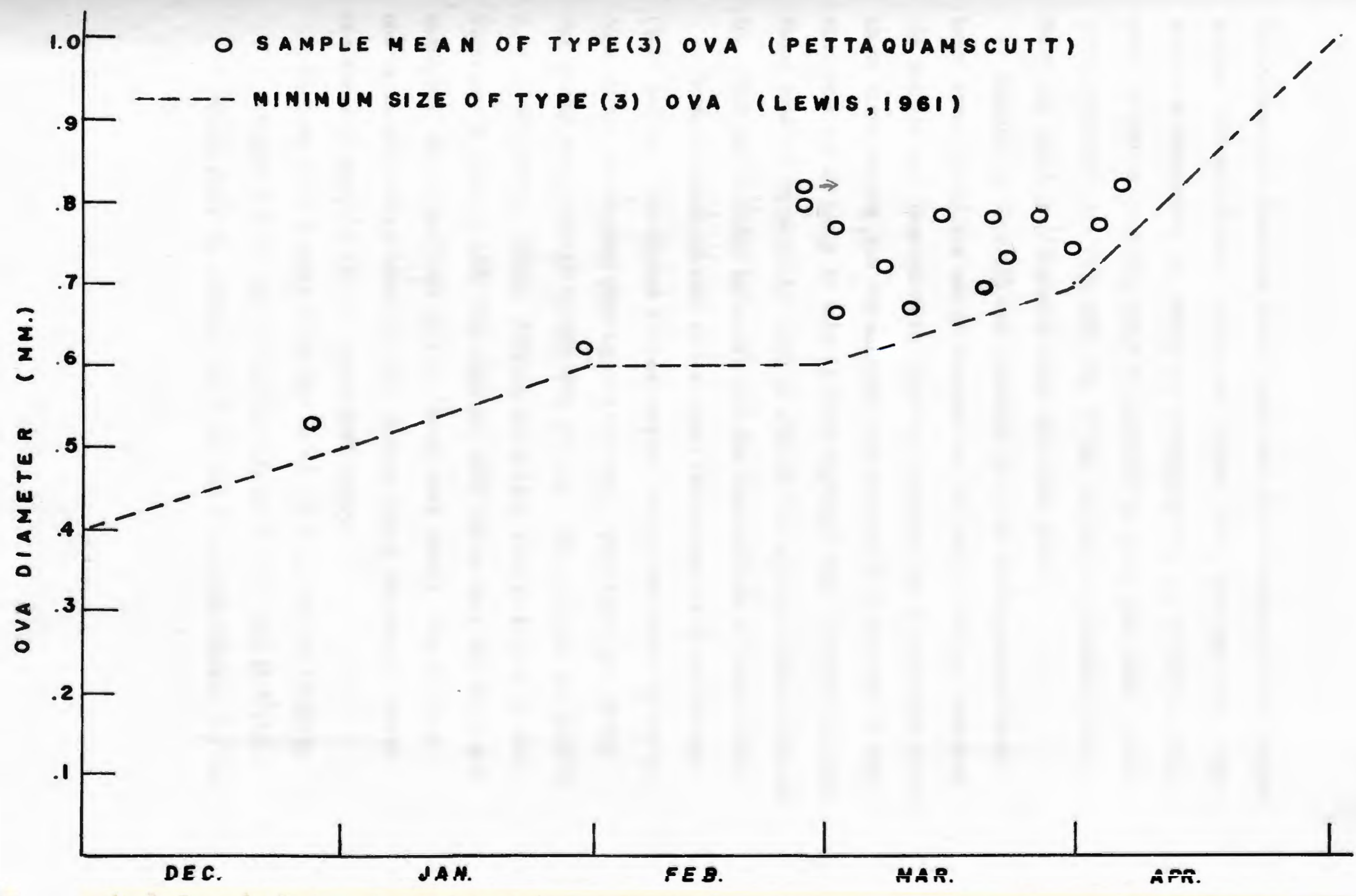


The average ova diameters during March and the beginning of April ranged between .70 and $.85 \mathrm{~mm}$. Jackson and Tiller (1952) indicate that striped bass from Chesapeake Bay having ova averaging $0.75 \mathrm{~mm}$. or more in diameter in the early spring could be expected to spawn that year. Lewis (1961) contends that fish with ova $.70 \mathrm{~mm}$. or more in diameter during March and April in Albermarle Sound will also spawn.

Averages of type (3) ova diameters from the Pettaquamscutt River bass, taken during the end of December and the end of January measured .55 and $.66 \mathrm{~mm}$., respectively. Although sampling was intermittent during these first months, the ova measured from the few fish captured at this time were not as large in size as those captured late in March and April. There appeared to be an increase in size as the spawning season approached. This was in close agreement with the observations of Iewis (1961). Three stations Iocated in the upper Pettaquamscutt River Estuary (I-1, I-2, and I-3; Figure 3) were sampled during the months of May and June, 1974, for striped bass eggs and larvae. Sampling began on the 7 th of May and continued to the 13 th of June. Each station was sampled a total of thirteen times. Surface and botton tows were made at each station. A total of 1022 fish eggs and 2580 larvae were collected and examined. No striped bass eggs or larvae were found. Temperatures and salinity readings taken at each station during the sample period are shown in Appendix (3) and summarized below.

Station I-1. Average depth was $10 \mathrm{ft} .(3 \mathrm{m.})$, surface salinity averaged $6.3 \%$ and eluctuated between $1.5 \%$ and $11.0 \%$ Bottom salinity averaged $12.8 \%$ and fluctuated between $9.1 \%$ 
and $16.9 \%$ oo. Surface temperatures averaged $16.6^{\circ} \mathrm{C}$ and increased from $14.5^{\circ} \mathrm{C}$ at the beginning of the sample period to $22.7^{\circ} \mathrm{C}$ at the end. Bottom temperatures averaged $12.7^{\circ} \mathrm{C}$ and increased from $9.1^{\circ} \mathrm{C}$ to $18.5^{\circ} \mathrm{C}$.

Station I-2. Average depth was $10 \mathrm{ft} .(3 \mathrm{m.})$, surface salinity averaged $8.2 \%$ and fluctuated between $7.4 \%$ and $10.1 \%$ Bottom salinity averaged $11.9 \%$ and fluctuated between $10.8 \%$ and $16.2 \%$. Surface temperatures averaged $18.0^{\circ} \mathrm{C}$ and increased from $14.7{ }^{\circ} \mathrm{C}$ at the beginning of the sample period, to $23.4^{\circ} \mathrm{C}$ at the end. Bottom temperatures averaged $15 \cdot 9^{\circ} \mathrm{C}$ and ranged from $12.0^{\circ} \mathrm{C}$ to $21.6^{\circ} \mathrm{C}$.

Station I-3. Average depth was $10 \mathrm{ft} .(3 \mathrm{m.})$, surface salinity averaged $11.1 \%$ and fluctuated between $8.6 \%$ and $17.5 \%$ Bottom salinity averaged $17.7 \%$ and fluctuated between $11.9 \%$ and $25.8 \%$ oo. Surface temperatures averaged $17.8^{\circ} \mathrm{C}$ and increased from $16.6^{\circ} \mathrm{C}$, at the beginning of the sample period, to $23.2^{\circ} \mathrm{C}$ at the end. Bottom temperatures averaged $15.7^{\circ} \mathrm{C}$ and increased from $12.1^{\circ} \mathrm{C}$ to $20.9^{\circ} \mathrm{C}$. 


\section{DISEUSSION}

\section{Abundance and Distribution}

It was not possible to make valid estimates of the population size of striped bass which overwinter in the Pettaquanscutt River Estuary. During the 1950's substantial numbers of bass were reported to have been taken from the area by a commercial seine operation (Wilfred Clark, commercial fisherman; personal communication). During the present study a limited number of bass (twenty) were gillnetted in this same area. The low catch of striped bass was a result of, either a scarcity of fish in the area, or the inefficiency of the sampling method. It was possible that large comnercial catches resulted from using large seines which were able to cover a good percentage of the area in the upper Pettaquamscutt. The gillnets used during the present study were passive. They remained stationary and depended on the movement of the fish to the net rather than the net to the fish. Although striped bass are very active fish, winter water temperatures lower the fish's metabolism and limit movement. Merriman (1941) states "fish remaining in the northerm cold waters become dormant and inactive". A small number of encounters between fish and net could result in an even smaller catch.

During the first winter of sampling (1974), the one gillnet used was set randomly throughout both the north and south basins. Changing the location of the net did not make much difference in the catch when compared to the two nets kept stationary during the following year. Nine bass were taken from the one net used during the first year. The 
following year five and six bass were taken from stations $G-1 \mathrm{a}$ and $G-2 b$ respectively. Although the gillnet may have been placed in the vacinity of fish as it was randomly relocated, the lethargic nature of the fish during this period may have been sufficient to reduce or eliminate contact between fish and the net.

Catch data was not sufficient to determine any patterns of distribution for overwintering striped bass in the sample area. During the first season, all gillnetted bass were taken from the same general area of the lower basin ( $G-1 a$ and $G-2 b)$. The following year bass were taken from both of the sampling stations in the lower basin ( $G-1 b$ and $G-2 b$ ). It was surprising that no bass were taken from the northern basin durIng either years. No explanations are available.

Measurements of anmual temperature profiles by previous investigators of the Pettaquamscutt River Estuary (Horton, 1958; Miller, 1972; and Gaines, 1975) show the first substantial increase in water temperature to occur during the manth of April. By the end of April surface temperatures reach as high as $16^{\circ} \mathrm{C}$. Merriman (1941) observed that the appearance of the first migrating striped bass in the New England area was closely associated with a rise in water temperature. The sudden increase in water temperature may stimulate coastal migrations of striped bass. This stimulus may have also affected the overwintering bass of the Pettaquamscutt River. In the present study, the last date that striped bass were taken during either season of winter sampling (1974 and 1975) was April eighth. The nets remained until the fifteenth of April the first year and the fifteenth of May the second. It was possible that the overwintering population moved out of the upper Pettaquamscutt with the increase in 
water temperatures and that the early migrants from the south had not yet entered the area. Sport fishing for early migrants is very active in the lower portion of the Pettaquamscutt during the months of April and May. Perhaps these fish do not move into the upper area until later in the season. Horton (1958) did not observe striped bass in the upper Pettaquamscutt until the months of June, July, August and September. If striped bass had remained in the upper Pettaquamscutt, or if early migrants entered, the increase in temperature should have caused an in crease in activity. Any increase in activity would have caused an increase in the frequency fish were gillnetted. Striped bass populations in the Thames River Estuary did not disappear during the spring and summer months (Maltezos, 1960). Early migrants may immediately displace or combine with the Thames River overwintering population; thus, fish are present throughout the entire year.

A system which would give accurate information on the population density, distribution, and movement throughout the present study area should be considered. Estimates on the density of sockeye salmon (Oncorhynchus nerka), before and after spawning in Iake Washington, were obtained using a hydro acoustical system (Thorne and Dawson, 1974). Surveys were made of large fish targets by running a series of transects throughout the entire lake. Changes in fish density, estimate by hydro acoustics compared with data from empirical wier counts and spawning ground surveys. A similar type system may have application in the upper Pettaquamscutt.

\section{Population Structure}

Early studies (Merriman, 1941) of the migratory component of striped 
bass most often found three and four year-old immature females to be most abundant in the New England area. This is not surprising since striped bass do not migrate out of Chesapeake Bay until their third summer. Chapton and Sykes (1961) report that larger fish (six year-olds and up) comprise a much smaller portion of the total catch along the coast. These large fish represented the small percentage which escape the heavy natural and fishing mortality which occurs during the first four years of life. Age class frequencies based on 216 angler caught fish in Maine (Davis, 1966) showed four yearolds to the most abundant group sampled.

It was not possible to obtain large numbers of overwintering striped bass for the present study. However, the year class composition of the small number obtained should be considered. Only one bass out of twentytwo was less than five years old; most were between six and eight years old. The absence of three year-olds and the low number of four and five year-olds is surprising. This may have been the result of poor year class production. Fluctuations in year class strength cause cycles in striped bass abundance (Merriman, 1941). A formula for predicting the relative abundance of the migratory striped bass (Schaefer, 1972) involved matching the abundance of the 0 year class fish in Chesapeake Bay with New York landings. Because striped bass do not migrate north until their third summer, there is a two year lag in the appearance of these fish along the Middle Atlantic and New England coast.

Young of the year surveys conducted in Chesapeake nursery waters (Boone and Florence, 1975) show the 1970 year class to be the strongest of the last twenty years. This year class would appear as four and five yearmold fish during 1974 and 1975 respectively, and should have made 
up a large percent of the year class distribution of the present study's samples. No bass representing this year class were taken during 1974 and only two were taken during 1975 ( $9.0 \%$ of the total sample).

It was possible that the absence of these smaller size fish was the result of the selectivity of the sampling gear. The relationship between mesh size of gillnets and the particular size range of fish most vulnerable has been discussed by Regier and Robson (1966), Hamley (1972) and Hamley and Regier (1973). Mansueti (1961) sampled striped bass with gillnets having 3, 4, and 5 inch stretched mesh. Large numbers of two, three, and four yearmold striped bass were gillnetted. The size range of fish captured was 27 to $55 \mathrm{~cm}$. Gillnets used during the present study included 3, 4, and 5 square mesh $(6,8$, and 10 inch stretched mesh). If three and four year-old bass were present in the Pettaquamscutt this larger size mesh may not have been effective in capturing representative numbers. These nets may select toward larger fish as indicated by the size range ( 55 to $121 \mathrm{~cm}$. ) of fish gillnetted during the winters of 1974 and 1975.

With the exception of one fish (4.5\%) the other twenty-one striped bass examined during the study were females. Sex ratios of striped bass sampled in northern waters characteristically favor females. Males represented anly 7.4\% of striped bass sampled in the Gulf of Maine (Davis, 1966). Merriman (1941) found that males comprised 9.7\% of striped bass sampled from Long Island and New Fngland waters. Populations sampled from the Connecticut and Thames River Estuaries (Maltezos, 1960) contained 11 and $12 \%$ males, respectively. 


\section{Spawning}

No evidence of striped bass spawning in the upper Pettaquanscutt River Estuary was obtained. If striped bass spawning did occur in this area, it was insignificant. The large number of eggs and larvae of other species document the usage of this area as a spamning and nursery ground.

Although the ova of gillnetted fish from the Pettaquamscutt showed normal development during the late winter and early spring, the fact that no striped bass eggs or larvae were found is not surprising. There was no evidence that the overwintering fish actually remained until the spawning season. If the overwintering population did remain in the area (undetected) the absence of a sufficient number of males might have been a Iimiting factor in the sparning success. Sex ratios obtained from spawning populations in sothern waters indicate a much larger representation by males (Pearson, 1938; and Merriman, 1941). Vladykor and Wallace (1952) report that males comprised as much as $83 \%$ of samples taken during March. Accounts of spawning activity include descriptions of individual females surrounded by many males (Bigelow and Schroeder, 1953).

Any consideration of striped bass reproduction in the study area should also include its suitability as a spaming ground. Environmental requirements necessary for spawning and survival of early life stages were discussed by Talbot (1966). Examination of the major spawning areas reveal that proper water temperatures and salinity are among the essential requirements necessary for spawning success.

Optimum water temperature for spawning striped bass range between 
$14^{\circ}$ and $22^{\circ} \mathrm{C}$. The poak of spawming occurs between $15^{\circ}$ and $19^{\circ} \mathrm{C}$. Egg and larvae sampling in the upper Pettaquanscutt was conducted between temperatures of approximately the same range. The surface and bottom temperatures of all ichthyoplankton stations were below $15^{\circ} \mathrm{C}$ when sampling conmenced on the seventh of May. By the end of the sampling period (June fifteenth) all surface temperatures had exceeded $21^{\circ} \mathrm{C}$. Bottom temperatures at stations I-2 and I-3 had reached $21^{\circ} \mathrm{C}$; however, bottom temperatures at station I-1 were still quite cool. Station I-1 was located close to the fresh water source of Gilbert Stuart Brook which may account for its erratic temperature.

The question of salinity raises serious doubts as to the suitability of this area as a spawning ground. The only major freshwater influance in the upper basin was Gillbert Stuart Brook. Station I-1 was located very close to the mouth of this stream. During sampling the surface salinity was seldam lower than $5 \%$. The limited fresh water area available to spawning fish, may be significant, as this is a major requirement. Although various investigators have found striped bass eggs and larvae drifting in brackish water, there has never been any conclusive evidence that spawning occurs in saline water (Talbot, 1966). 


\section{CONCLUSIONS}

1. Results of two winters of gillnetting in the upper Pettaquamscutt River Estuary suggest that the overwintering population of striped bass in this area may not be very large. Although sampling continued as late as the middle of May, no striped bass were taken after the eighth of April during either year. It was possible that the overwintering population left the area with an increase in temperature during the month of April.

2. Year class frequencies of the sample from the overwintering population show a lack of 3,4 , and 5 year old bass. The selectivity of the sampling gear (gillnets) may have accounted for the absence of small fish.

3. Comparison of ova diameters from Pettaquanscutt bass with bass from established southern spawning grounds, show similar development, and imply that normal gonadal maturation is not inhibited by winter conditions in northern waters.

4. The early disappearance of fish from the area in addition to the fact that very few males would have been present if fish did remain until the spawning season, may account for the absence of striped bass eggs and larrae during 1974. The suitability of the upper Pettaquamscutt River Estuary as a striped bass spawning ground may be questionable due to the high salinity levels. 
Bigelow, H. B. and W. C. Schroeder. 1953. Fishes of the Gulf of Maine. 1st revision, Fish. Bull. Fish. Wildlive Serv., $53(74): 1-577$.

Boone, Joseph G. and Benjamin M. Florence. 1976. The status of striped bass - and Maryland's role in the fortunes of this valuable fish. Misc. report.

Chepoton, R. B. and J. E. Sykes. 1961. Atlantic Coast Migration of Large Striped Bass as Evidenced by Fisheries and Tagging. Tran. Am. Fish. Soc. 90(1): 13-20.

Davis, Robert H., Jr. 1966. Population studies of striped bass, Roceus saxatilis (Walbaum), in Maine based on age distribution and growth rate. M.S. Thesis, Univ. of Meine, Orono, $51 \mathrm{pp}$.

Gaines, Arthur George. 1975. Papers on the geomorphology hydrography and geochemistry of the Pettaquanscutt River Estuary. Ph.D. Thesis, University of Rhode Islarid.

Hamley, J. M. 1972. Use of the Delury Method to estimate gillnet selectivity. J. Fish. Res. Board Can. 29: 1636-1638.

Hamley, J. M. and H. A. Regier. 1973. Direct estimates of gillnet selectivity to walleye (Stizostedion vitreum). J. Fish. Res. Board Can. 30: 817-830.

Hortan, D. B. 1958. The Occurrences and Distribution of Fish in Upper Pettaquamscutt River. M.S. Thesis, University of Rhode Island.

Hollis, E. H. and H. A. Davis. 1955. Report of striped bass studies in Maryland. 14th Annual Meeting, Atlantic St. Mar. Fish. Comm., Nov. 14-15, 1955. Virginia Beach, VA., Appendix CB: 1-8.

Jackson, H. W. and R. E. Tiller. 1952. Preliminary observations on spawning potential in the striped bass (Roccus saxatilis, Halbaum). Md. Dept. Res. \& Ed., Ches. Biol. Lab. Publ. No. 93: 16 pp.

Koo, T. S. Y. 1970. The Striped Bass-Fishery in the Atlantic States. Chesapeake Sci. 11: 73-93.

Lewis, Robert M. 1961. Sexual maturity as determined from ovum diameters in striped bass from North Carolina. Trans. Amer. Fish. Soc. 91: 279-282. 
Maltezos, G. C. 1960. Striped bass investigation, Roccus saxatilis. Conn. St. Bd. Fish \& Game. $26 \mathrm{pp}$.

Mansueti, Romeo. 1958. Figgs, larvae, and young of the striped bass, Roccus sexatilis. Md. Dept. Research and Education, Cheas. Bio. Lab. (112): $1-35$.

Mansueti, Romeo. 1961. Age growth and movements of the striped bass, Roccus saxatilis, taken in size selective fishing gear in Maryland. Chesapeake Sci., $2(1 \& 2)$ : 9-36.

Merriman, D. 1941. Studies on the striped bass, Roccus saxatilis, of the Atlantic coast. U.S. Fish \& Wildlife SerV. Fish. Bull., Vol. 50 , No. 35 , pp. 1-77.

Miller, Boyce T. 1972. The phytoplankton and related hydrography in the south basin of the Pettaquanscutt River. M.S. Thesis, University of Rhode Island.

Moore, Charles J. and Dennis Burton. 1975. Movements of striped bass, Morone saxatilis, tagged in Maryland waters of Chesapeake Bay. Trans. Amer. Fish. Soc. 104(4): 703-709.

Mulkana, Mohammed, Saeed. 1966. The growth and feeding habits of juvenile fishes in two Rhode Island estuaries. Gulf Research Reports, Vol. 2, pages 97-168.

Nichols, P. R. and R. V. Miller. 1967. Seasonal movement of striped bass, Roccus saxatilis (Walbaum), tagged and released in the Potomac River, Maryland, 1959-61. Chesapeake Sci., 8 (2): 102124.

Pearson, John C. 1938. The Iife history of the striped bass or rockfish, Roccus saxatilis (Walbaum). U.S. Bur. of Plsh., Bull. 28, (49): $825-851$.

Porter, John and Saul B. Saila. 1969. Cooperative Striped Bass Migration Study. Graduate School of Oceanography, University of Rhode Island and Bureau Sport Fish. \& Wildlife. Final Draft Report, Contract No. 14-16-0005, June 25, 1969: 33 pp.

Raney, E. C. 1952. The life history of the striped bass, (Roccus saxatilis, Walbaum). Bull. Binghan Oceanogr. Col., 14 (1): 5-97.

Regier, H. A., and D. S. Robson. 1966. Selectivity of gillnets, especially to Lake White Fish. J. Fish. Res. Bd. Canada, 23: $423-454$.

Rogers, B. A. and D. T. Westin. 1975. A Bibliogrephy on the Biology of Striped Boss, Morone saxatilis (Walbaum). Marine Technical Report No. 37, University of Rhode Island. 
Schaefer, Richard H. 1972. A short-range forecast function for predicting the relative abundance of striped bass in Long Island waters. N.Y. Fish and Game Jour., 19 (2): 178-181.

Smayda, T. J. and H. P. Jefferyes. 1954. Late winter and early spring plankton populations in the Pettaquamscutt River, a brackish estuary in Rhode Island. Unpublished report, Narragansett, Marine Lab.

Talbot, Gerald B. 1966. Estuarine requirements and limiting factors for striped bass. In a symposium on Estuarine Fisheries, Amer. Fish Soc., Spec. Publ. No. 3: 37-49.

Thorne, Richard E. and James J. Dawson. 1974. An Acoustic Estimate of the Escapement of Sockeye Salmon (Oncorhynchus nerka) into Lake Washington in 1971. Journal Fisheries Research Board of Canada, Vol. 31, No. 2, 1974, p. 222-225.

Vladykov, Vadim D. and D. H. Wallace. 1952. Studies of the striped bass, Roccus saxatilis (Walbaum), with special reference to the Chesapeake Bay Region during 1936-38. Bull. Bingham Oceanogr. Gol., 14 (1): 132-177.

Wright, T. J., C. J. Fish, R. Campbell, S. D. Hicks, R. L. McMaster and D. B. Horton. 1958. Pettaquanscutt River Investigation. University of Rhode Island, Narragansett Marine Laboratory, Mimeo Report. 


\section{APPENDIX 1}

Frequency in diameter size $(0.05 \mathrm{~mm}$.) measured from 100 ova which were taken from 16 overwintering striped bass of the Pettaquamscutt River Estuary during 1974 and 1975.

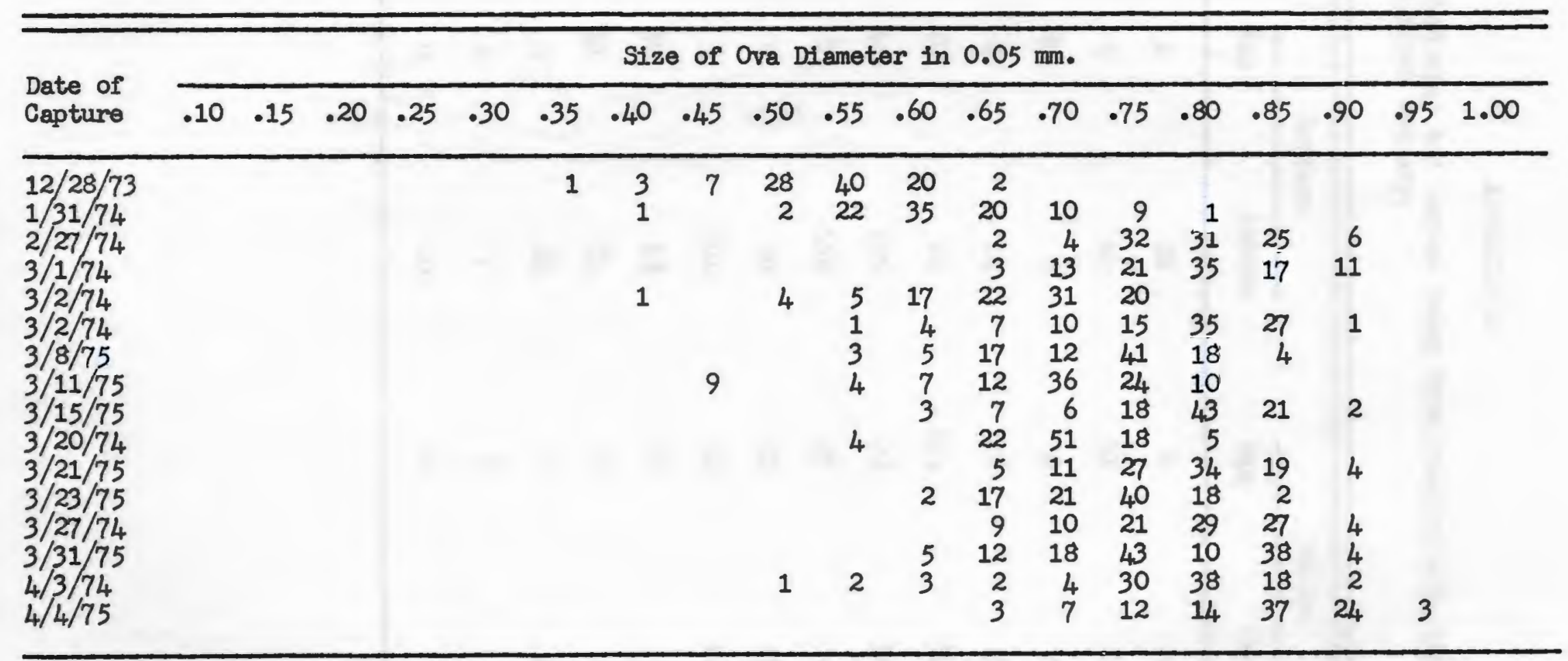




\section{APPENDIX 2}

Abundance of fish eggs and larvae taken from station I-2, upper Pettaquanscutt River Estuary.

\begin{tabular}{|c|c|c|c|c|}
\hline \multirow[b]{2}{*}{ Date } & \multicolumn{2}{|c|}{ Surface } & \multicolumn{2}{|c|}{ Bottom } \\
\hline & Egg & Iarvae & Egg & Larvae \\
\hline $5 / 7 / 74$ & 1 & 26 & 0 & 15 \\
\hline $5 / 11 / 74$ & 1 & 61 & 31 & 21 \\
\hline $5 / 13 / 74$ & 20 & 5 & 0 & 61 \\
\hline $5 / 15 / 74$ & 0 & 14 & 10 & 41 \\
\hline $5 / 17 / 74$ & 10 & 62 & 104 & 101 \\
\hline $5 / 19 / 74$ & 41 & 115 & 72 & 151 \\
\hline $5 / 21 / 74$ & 7 & 152 & 67 & 67 \\
\hline $5 / 24 / 74$ & 0 & 50 & 61 & 151 \\
\hline $5 / 28 / 74$ & 3 & 101 & 54 & 104 \\
\hline $5 / 31 / 74$ & 10 & 52 & 21 & 91 \\
\hline $6 / 3 / 74$ & 11 & 51 & 21 & 9 \\
\hline $6 / 6 / 74$ & 0 & 20 & 0 & 42 \\
\hline $6 / 9 / 74$ & 0 & 0 & 0 & 1 \\
\hline $6 / 13 / 74$ & 0 & 40 & 0 & 9 \\
\hline
\end{tabular}


APPENDIX 2

Abundance of fish eggs and larvae taken from Station I-1, upper Pettaquamscutt River Estuary.

\begin{tabular}{|c|c|c|c|c|}
\hline \multirow[b]{2}{*}{ Date } & \multicolumn{2}{|c|}{ Surface } & \multicolumn{2}{|c|}{ Bottom } \\
\hline & Egg & Larvae & Egg & Larvae \\
\hline $5 / 7 / 74$ & 1 & 12 & 0 & 0 \\
\hline $5 / 11 / 74$ & 0 & 18 & 13 & 4 \\
\hline $5 / 13 / 74$ & 9 & 8 & 17 & 20 \\
\hline $5 / 15 / 74$ & 0 & 9 & 1 & 20 \\
\hline $5 / 17 / 74$ & 22 & 20 & 15 & 9 \\
\hline $5 / 19 / 74$ & 25 & 75 & 30 & 10 \\
\hline $5 / 21 / 74$ & 14 & 61 & 3 & 12 \\
\hline $5 / 24 / 74$ & 0 & 33 & 0 & 19 \\
\hline $5 / 28 / 74$ & 9 & 40 & 4 & 16 \\
\hline $5 / 31 / 74$ & 15 & 15 & 3 & 10 \\
\hline $6 / 3 / 74$ & 2 & 41 & 0 & 0 \\
\hline $6 / 6 / 74$ & 0 & 0 & 0 & 0 \\
\hline $6 / 9 / 74$ & 0 & 0 & 0 & 0 \\
\hline $6 / 13 / 74$ & 0 & 0 & 0 & 0 \\
\hline
\end{tabular}


APPENDIX 2

Abundance of fish eggs and larvae taken from station I-3, upper Pettaquanscutt River Estuary.

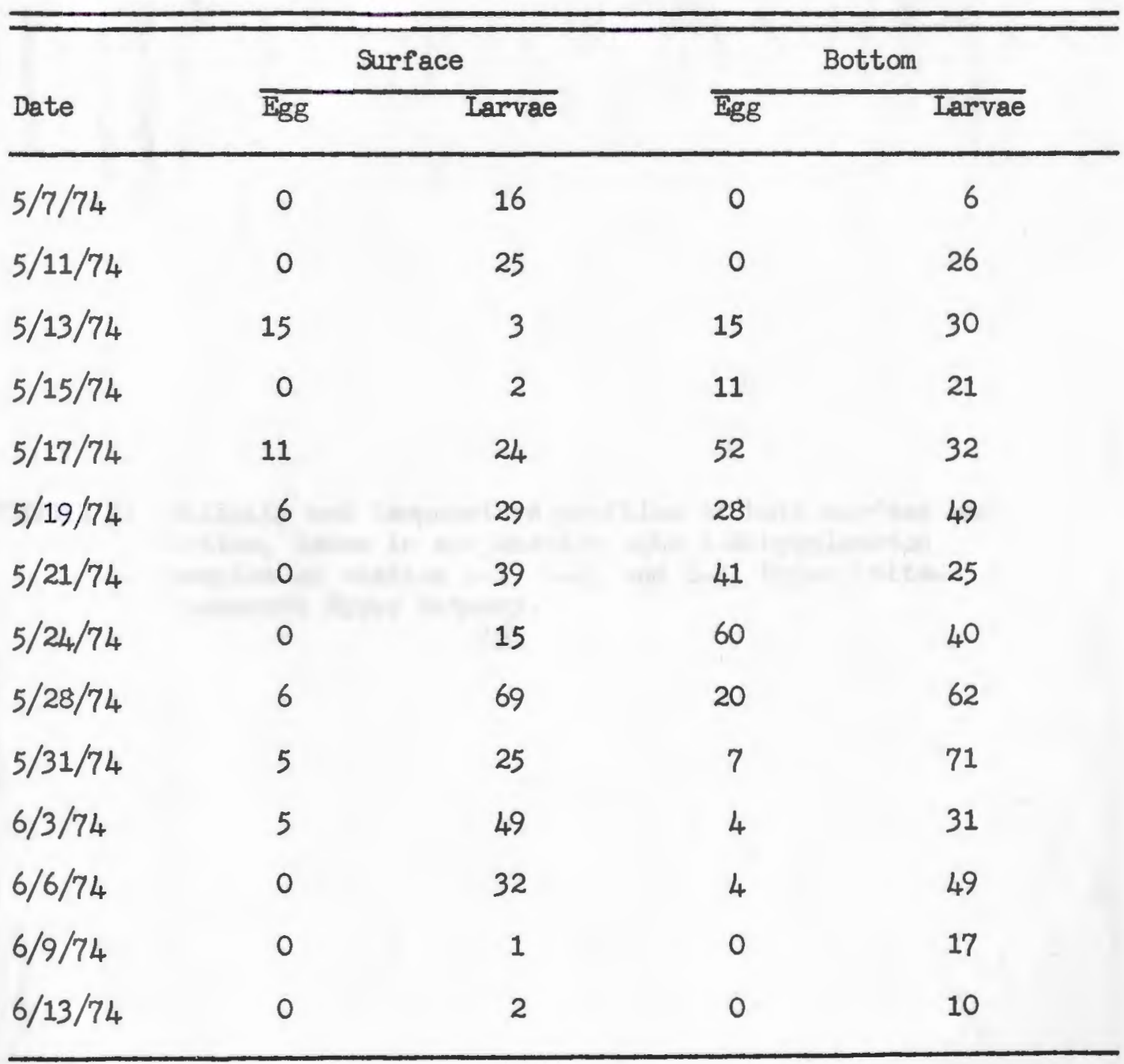


APPENDIX 3. Salinity and temperature profiles of both surface and bottom, taken in conjunction with ichthyoplankton samples at station I-1, I-2, and I-3, Upper Pettaquamscutt River Estuary. 


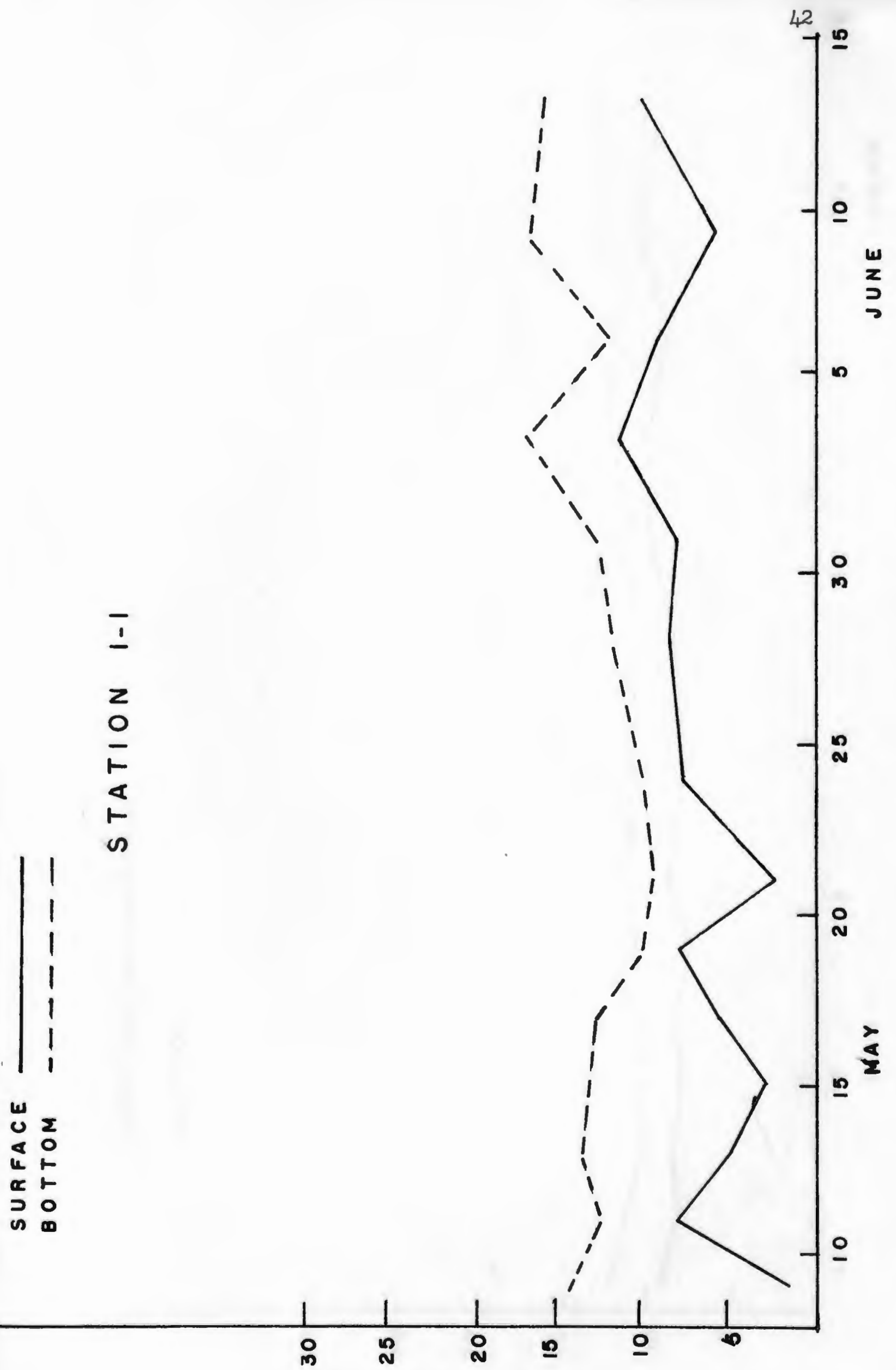




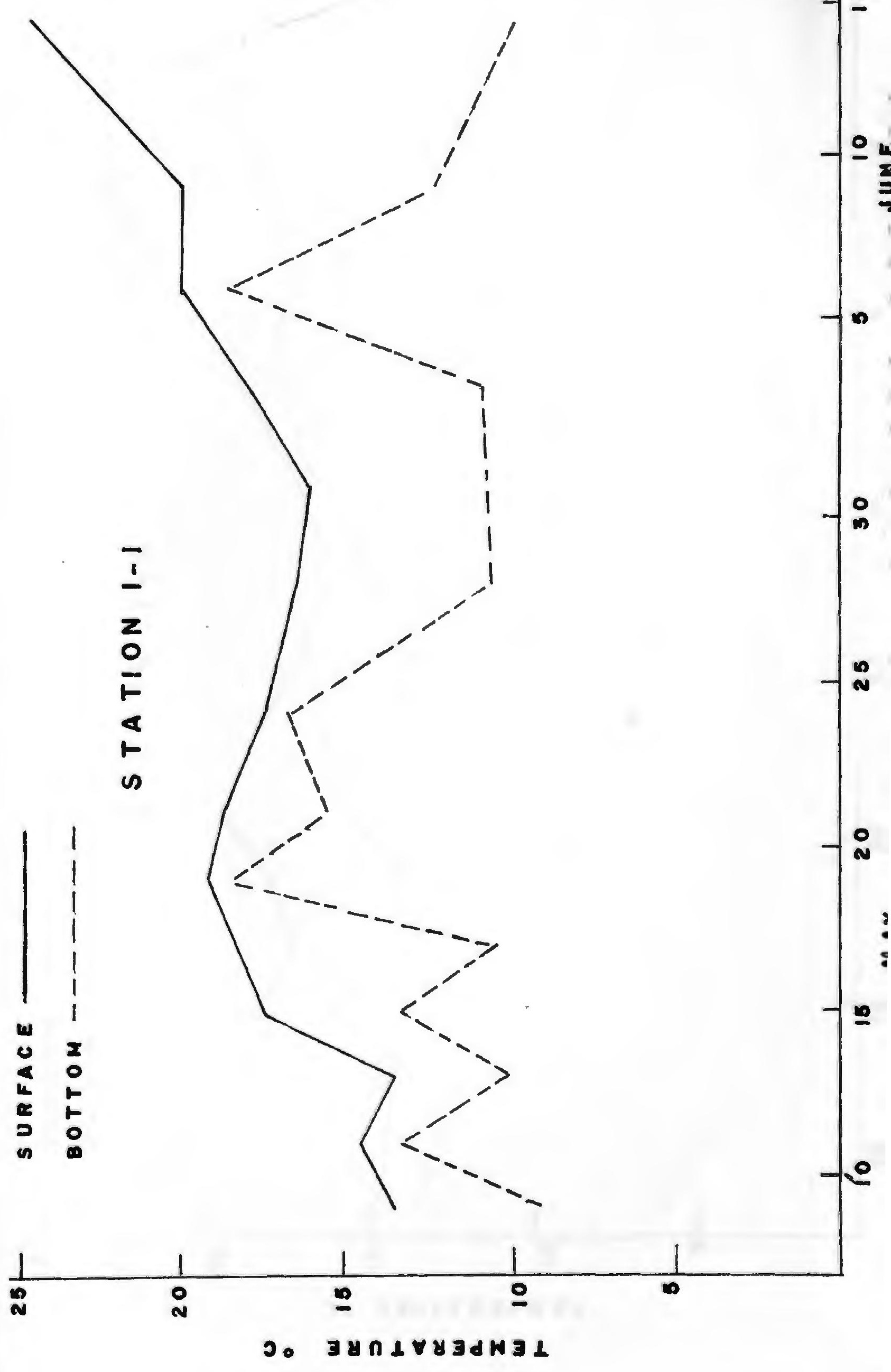




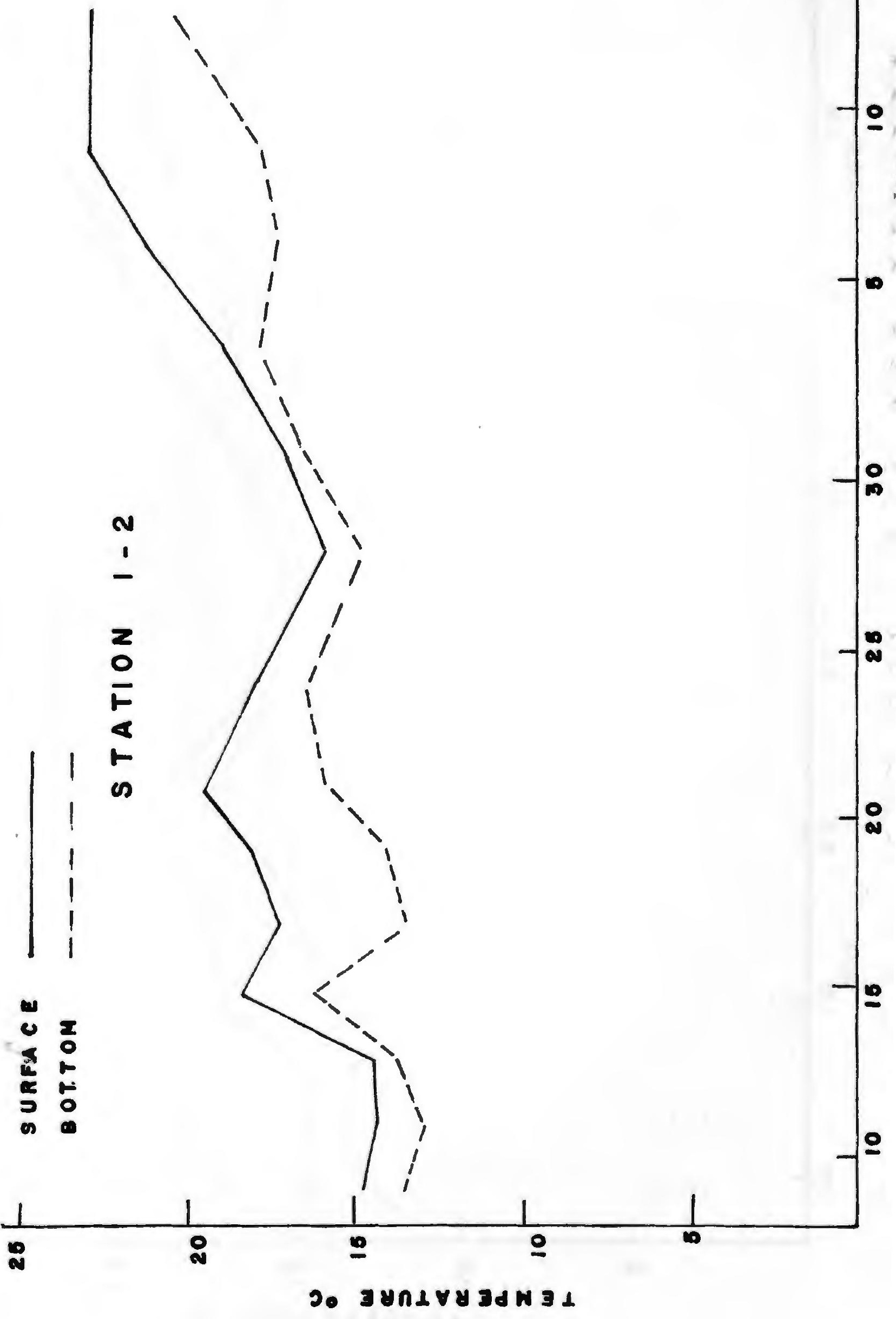




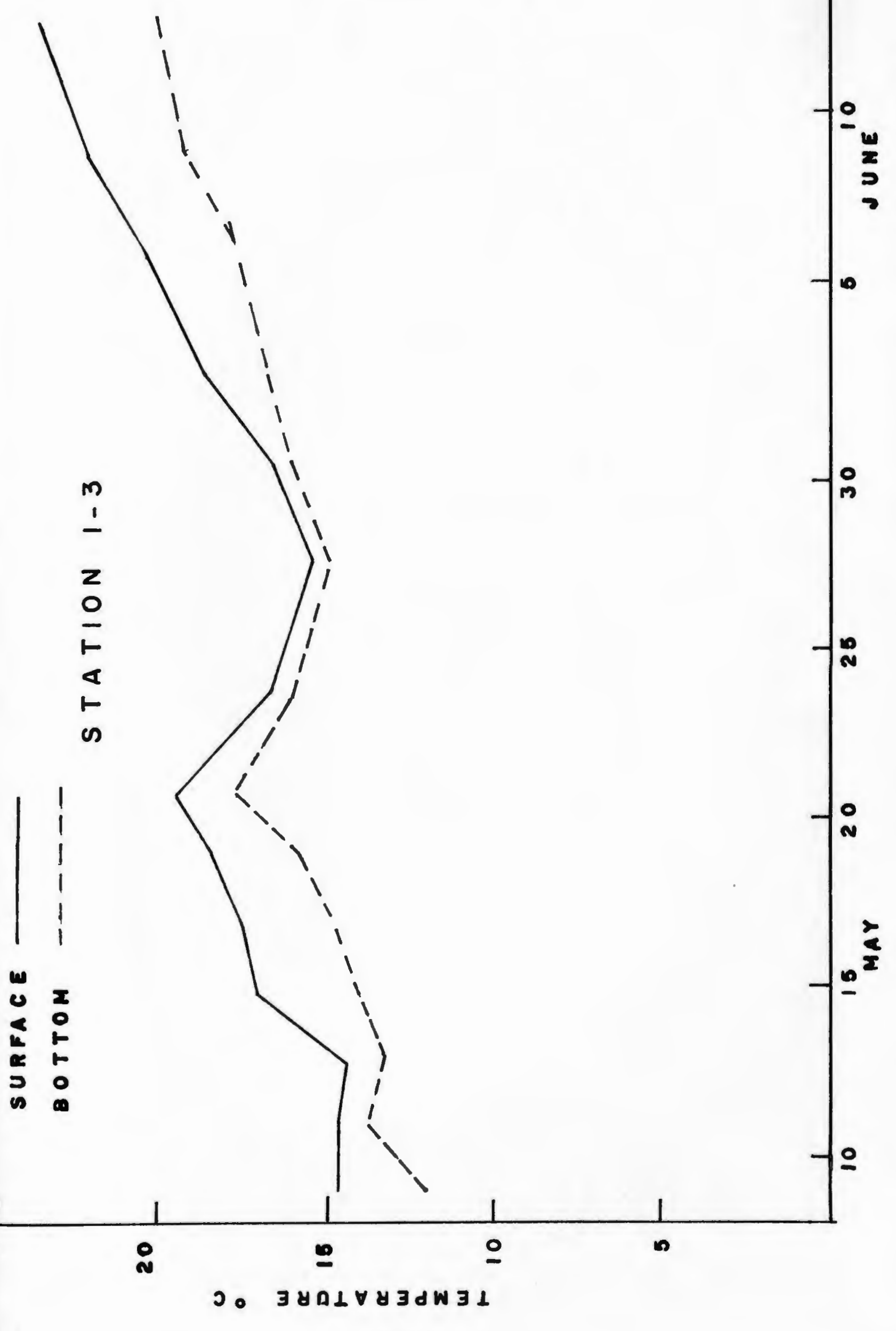

